RESEARCH ARTICLE - ANTS

\title{
First-year nest growth in the leaf-cutting ants Atta bisphaerica and Atta sexdens rubropilosa
}

\author{
SRS CARDOSO ${ }^{1,2}$, LC FORTI $^{1}$, NS NAGAMOTO ${ }^{1}$, RS CAMARGO ${ }^{1}$ \\ 1 - Universidade Estadual Paulista (UNESP), Botucatu, São Paulo, Brazil \\ 2 - Instituto Federal do Tocantins, Araguatins, Tocantins, Brazil
}

\author{
Article History

\section{Edited by} \\ Evandro N. Silva, UEFS, Brazil \\ Received 15 July 2013 \\ Initial acceptance 09 August 2013 \\ Final acceptance 08 July 2014

\section{Keywords} \\ initial chamber, leaf-cutting ant, \\ nest architecture, nest foundation, \\ excavation \\ Corresponding author \\ Nilson Satoru Nagamoto \\ Depto. Proteção Vegetal, FCA, UNESP \\ PO Box 237, Botucatu, SP, Brazil \\ 18.610-307 \\ Tel. +55 1438117167 \\ Fax: +55 14 38117206E \\ E-Mail: nsnagamoto@yahoo.com
}

\begin{abstract}
Most ants, as leaf cutting ants, construct nests underground to maintain environmental conditions favorable to the development of immature and adult individuals. But there was little works about this, especially doing comparison of nest growth among leafcutting ant species. Thus, we studied the growth of nests of the leaf-cutting ants Atta bisphaerica and Atta sexdens rubropilosa from nest foundation until the appearance of a second chamber. To this end, we verified the measurements of the chamber recently constructed by the queen and monitored its growth in the initial phase of nest development. The nests were marked immediately after nuptial flight, with 40 nests of each species being dug at 45, 90, 135, 180, and 225 days afterwards. As a result, it was found a first time statistical demonstration that an ellipsoid chamber shape was verified in both species in the initial chamber at 45 days, and that, after, these chamber became spherical. In general, chamber size increased and format change was found in both species. The depth of the first chamber was found to increase significantly only in $A$. bisphaerica; this result means that this chamber growths downside rather than upside. The occurrence of a second chamber was verified from six months after nest foundation, in both species. Our study contributes to knowledge of the colony development for up to 1 year, by performing comparison of two leaf-cutting ants species.
\end{abstract}

\section{Introduction}

Most ant species construct their nests underground, which promotes protection for the colony and aids in the maintenance of environmental conditions, facilitating the development of immature and adult individuals (Hölldobler \& Wilson, 1990). However, nest construction requires intensive labor by the ants to excavate the soil (Halley et al., 2005).

In the genus Atta F. 1805 (Hymenoptera: Formicidae) the adult nests are formed by numerous interconnected chambers, reaching several meters in depth, with deposition of soil on the surface, forming a pile of loose soil (Gonçalves, 1960; Araújo \& Della Lucia, 1997). Such chambers may present variations in format, localization and dimensions depending on the species and function (fungus, waste and soil) (Moreira, 2001). Despite such knowledge, little is known about the initial growth of nests formed by this genus.

In most social insects the size of the nest is a function of its population; however the dynamic of construction and enlargement of underground nests is not fully known (Rasse \& Deneubourg, 2001). In Atta, the work of nest foundation is performed by a single recently fecundated queen that constructs the first chamber (Autuori, 1942; Ribeiro, 1995; Camargo et al., 2011; Fröhle \& Roces, 2012). After the first worker ants initiate foraging, they assume activities within and outside of the nest, including the excavation of new tunnels and chambers (Autuori, 1942; Amante, 1972); so, the nest enlargement is thus the responsibility of adult offspring. Furthermore, the initial chamber is also enlarged each day by the excavation effort of the worker ants (Jacoby, 1943). Some 
studies indicate that for several species of ants the nest size is adjusted to the population (Rasse \& Deneubourg, 2001; Buhl et al., 2004; Mikheyev \& Tschinkel, 2004; Camargo \& Forti, 2014; Römer \& Roces, 2014).

Although the genus Atta presents the ability to construct deep nests, the initial chamber is based in the topsoil layer at a depth of about 8.5 to $15 \mathrm{~cm}$ (Autuori, 1941), and is subject not only to variations in temperature and humidity, but also to the influence of strong and abundant rains that are typical of the period in which nest foundation occurs (Autuori, 1941; Bento et al., 1991).

Therefore, one of the most important aspects in the study of Atta is undoubtedly the knowledge of its initial development, which can be externally monitored through measurements of the nest openings and the soil mound (Mariconi, 1970) and internally by means of excavations, to ascertain, for example, the depth and size of the first chambers constructed. Although there have already been reports on the chamber format and initial chamber depth of Atta (Autuori, 1942; Jacoby, 1943, 1950; Mariconi, 1970), the literature on the foundation and initial development of Atta nests remains highly limited.

Due to the scarcity of biological information on nests of Atta species in their first year of life, the present paper studied the growth and morphology of nests in two species which exhibit contrasting adaptations: Atta bisphaerica Forel 1908, which nests in full sun and foraging predominantly grasses, and Atta sexdens rubropilosa Forel 1908, which nests in shaded places and forages dicots (Mariconi, 1970; Fowler et al., 1986; Nagamoto et al., 2009).

\section{Material and Methods}

The work was conducted in the city of Botucatu, Sao Paulo state, Brazil with the $A$. bisphaerica nests studied in a pasture area of Santana Farm $\left(22^{\circ} 50.720^{\prime} \mathrm{S}\right.$ and $48^{\circ} 26.155^{\prime}$ $\mathrm{W})$, and the $A$. sexdens rubropilosa nests being selected in an area of Eucalyptus plantations belonging to FCA/UNESP, Botucatu, SP $\left(22^{\circ} 50.833^{\prime} \mathrm{S}\right.$ and $\left.48^{\circ} 26.476^{\prime} \mathrm{W}\right)$. Both areas present the Oxisol soil type (Dark Red Latosol). In each area 500 nests were randomly selected at the moment of nest foundation by the queen in October 2007. The nests were marked by labeled wire stakes.

The excavations were performed with using digging tools (such as shovels, picks and spatulas) by opening a trench at the side of the nest, carefully exposing the channel and chamber as described by Autuori (1942), Pereira-daSilva (1979) and Pretto (1996), and then the biomass (fungus garden, ants and brood) was discarded. Forty nests of each species were excavated at 45, 90, 135, 180 and 225 days after nest foundation (a total of 400 nests). The measurements, including depth, length, width, and height were obtained for each excavated nest (Figure 1).

\section{Format of the initial chamber}

Based on the geometric aspect, some authors have defined the format of the chamber for the cultivation of fungi, as typically spherical or ellipsoid (Jacoby, 1950; Silva Junior et al., 2013). Here we purpose, for the first time (to our best knowledge), to classify the leaf cutting ant chamber statistically, taking into account that the ellipse and sphere posses well known coordinates: if the Cartesian coordinates $\mathrm{x}, \mathrm{y}$ and $\mathrm{z}$ are equal, it is a sphere; if there are differences, is ellipsoid. For this, we compared length (L), width (W) and height $(\mathrm{H})$, at each excavation period, using Analysis of Variance (ANOVA) $(\alpha=0.05)$.

\section{Volume of the chamber}

The volume of the chamber was monitored through comparison of each chamber measurements (L, W, H) among the periods studied: volume $=3 / 4 \pi \mathrm{LWH}$ (ellipsoid volume). For this, only the measurements of nests with alive queen were taken into account. The volume data among periods among a species, and in each period between these species, were submitted to Analysis of Variance (ANOVA) $(\alpha=0.05)$,

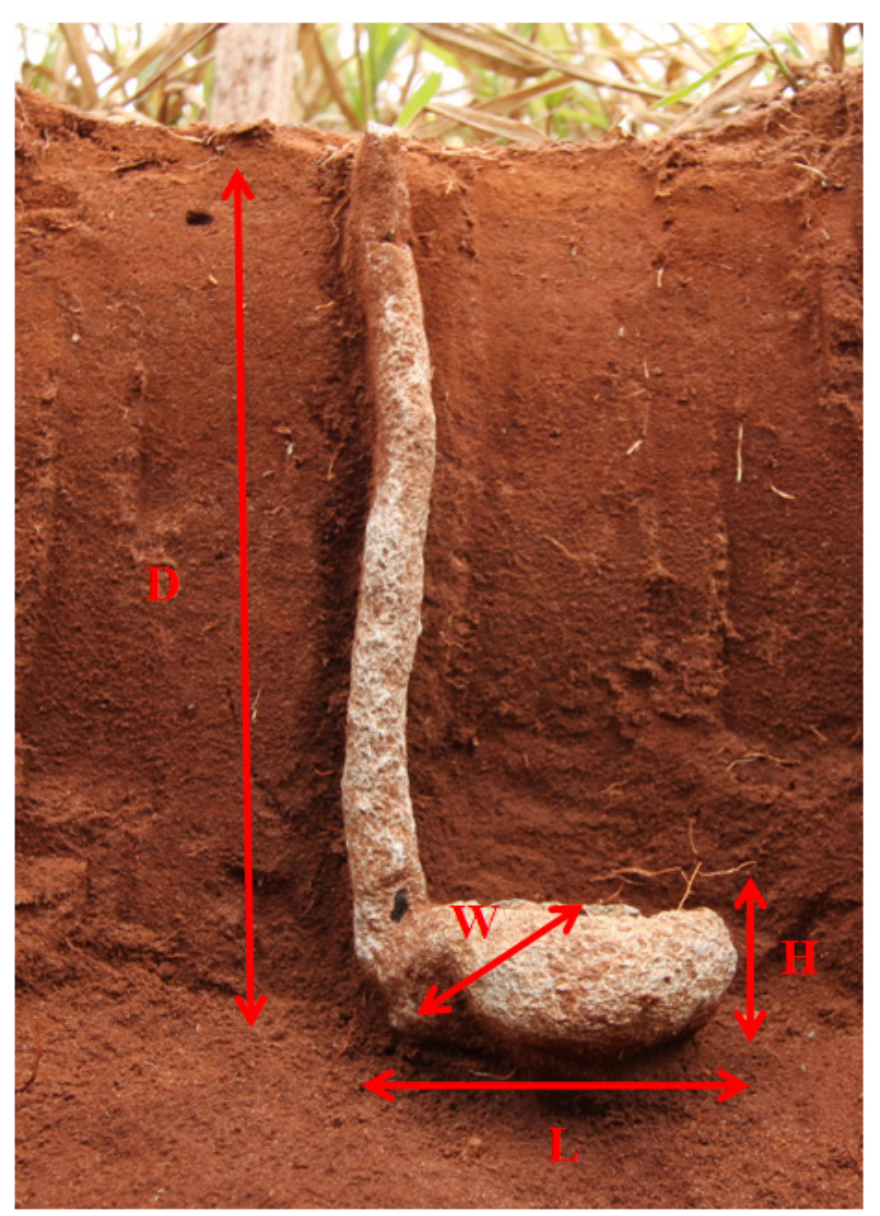

Figure 1. The measurements of depth (D), length (L), width (W) and height $(\mathrm{H})$ at a nest of Atta bisphaerica, that was cement-moulded (as in Moreira et al., 2004) to enable a better view. 
with the means compared by Bonferroni's test. To evaluate the difference in the depth of the chamber between the two species, their measurements in each period were compared and the data obtained were submitted to Student's t test $(\alpha=0.05)$.

\section{Results}

\section{Format of the initial chamber}

The initial chamber presented two distinct formats: first ellipsoid and spherical in the last periods of evaluation. A. bisphaerica showed an ellipsoid format until 90 days after foundation, with the dimensions of chamber differing significantly in 45 days $(\mathrm{p}<0.001)$ and 90 days $(\mathrm{p}=0.006)$ (Table 1). From 135 to 225 days after the foundation, the measurements did not differ from each other, indicating a spherical format.

In $A$. sexdens rubropilosa, it was verified a difference among the dimensions of chamber in 45 days $(\mathrm{p}<0.001)$. The change in format occurred after 90 days because ceased to exist significant differences between length, width and height $(\mathrm{p}>0.050)$ (Table 1).

Table 1. Summary statistic for values of ANOVA of the initial fungus chambers measurements (length, width and height), classification of the leaf-cutting ant initial chamber, statistically, into ellipsoid or spherical: if the Cartesian coordinates $\mathrm{x}, \mathrm{y}$ and $\mathrm{z}$ are not significantly different, it is spherical; if there are significant differences, is ellipsoid. Comparisons in each excavation period (day) for each species.

\begin{tabular}{ccccccc}
\hline Day & \multicolumn{3}{c}{ Atta bisphaerica } & \multicolumn{3}{c}{ Atta sexdens rubropilosa } \\
\hline & $P$ value & F & DF & $P$ value & F & DF \\
45 & $<0.001^{*}$ & 40.363 & 98 & $<0.001^{*}$ & 15.338 & 80 \\
90 & $0.006^{*}$ & 5.523 & 65 & $0.060^{n s}$ & 3.085 & 32 \\
135 & $0.137^{n s}$ & 2.040 & 83 & $0.226^{n s}$ & 1.596 & 23 \\
180 & $0.120^{n s}$ & 2.263 & 35 & $0.830^{n s}$ & 0.189 & 14 \\
225 & $0.631^{n s}$ & 0.470 & 26 & $0.366^{n s}$ & 1.127 & 11 \\
\hline
\end{tabular}

*Significant (= ellipsoid chambers); ${ }^{n s}$ non significant (= spherical chambers)

In $A$. bisphaerica, at 45 days, the dimensions are $(\mathrm{cm}$ $\pm \mathrm{SD})$ : the length $(4.28 \pm 0.65)$ differed from width $(3.04 \pm$ $0.37)$ and height $(3.33 \pm 0.68)$. For day 90 , the length $(5.14 \pm$ $1.21)$ differed only from width $(3.95 \pm 0.93)$. Later, the highest growth in width and height in relation to height, resulted in no significant differences between these measurements $(\mathrm{p}>0.050)$.

In A. sexdens rubropilosa, for day 45, the length (3.66 $\pm 0.57)$ differed from width $(2.89 \pm 0.80)$ and height $(2.76 \pm$ $0.52)$. Then, for both species, the width and height was the chamber measurements that grew most from 45 to 225 days.
Volume

The size of the initial chamber was growing significantly in both species (Fig. 2). In general, the mean measurements of the initial chamber were greater for $A$. bisphaerica than for A. sexdens rubropilosa, with volume differing significantly in many periods evaluated (Table 2). At 45, 135 and 225 days after foundation the volume was greater in $A$. bisphaerica than $A$. sexdens rubropilosa, significantly differing, $\mathrm{p}<0.001$, $\mathrm{p}=0.014$ and $\mathrm{p}=0.035$, respectively (Table 2).

Depth

The depth of the initial chamber was growing significantly for $A$. bisphaerica (Fig. 3), but not in $A$. sexdens rubropilosa. In general, chamber depth significantly differed between the ant species (Table 3), with $A$. bisphaerica showing deeper chambers (Fig. 3).

\section{Second chamber}

From 180 days, a new tunnel emanating down from the first chamber, it was always detected. The occurrence of a second chamber was verified from six months after nest foundation, in both species. For $A$. bisphaerica the mean measurements of the second chamber were: depth of $104.3 \pm$ $35.0 \mathrm{~cm}$, vol. of $29.4 \pm 28.7 \mathrm{~cm}^{3}$. For A. sexdens rubropilosa, a second chamber occurred in only two nests, with the first

Table 2. Students's $t$ test summary statistic for values of the initial fungus chamber volume between leaf-cutting ant species.

\begin{tabular}{clcc}
\hline Day & \multicolumn{3}{c}{ Atta bisphaerica vs Atta sexdens rupropilosa } \\
\hline & $P$ value & $t$ & DF \\
45 & $<0,001^{*}$ & 4,249 & 58 \\
90 & $0,133^{\mathrm{ns}}$ & 1,541 & 31 \\
135 & $0,014^{*}$ & 2,601 & 34 \\
180 & $0,589^{n s}$ & $-0,552$ & 15 \\
225 & $0,035^{*}$ & 2,411 & 11 \\
\hline
\end{tabular}

*Significant difference in $t$ test; ${ }^{n s}$ non significant difference in $t$ test.

Table 3. Students's $t$ test summary statistic for values of the initial fungus chamber depth between leaf-cutting ant species.

\begin{tabular}{|c|c|c|c|}
\hline \multirow[t]{2}{*}{ Day } & \multicolumn{3}{|c|}{ Atta bisphaerica vs Atta sexdens rupropilosa } \\
\hline & $P$ value & $t$ & DF \\
\hline 45 & $<0,001 *$ & 5,372 & 58 \\
\hline 90 & $0,002 *$ & 3,463 & 31 \\
\hline 135 & $0,009 *$ & 2,751 & 34 \\
\hline 180 & $<0,001 *$ & 4,831 & 15 \\
\hline 225 & $0,062^{\mathrm{ns}}$ & 2,081 & 11 \\
\hline
\end{tabular}

*Significant difference in $t$ test; ${ }^{n s}$ non significant difference in $t$ test. 

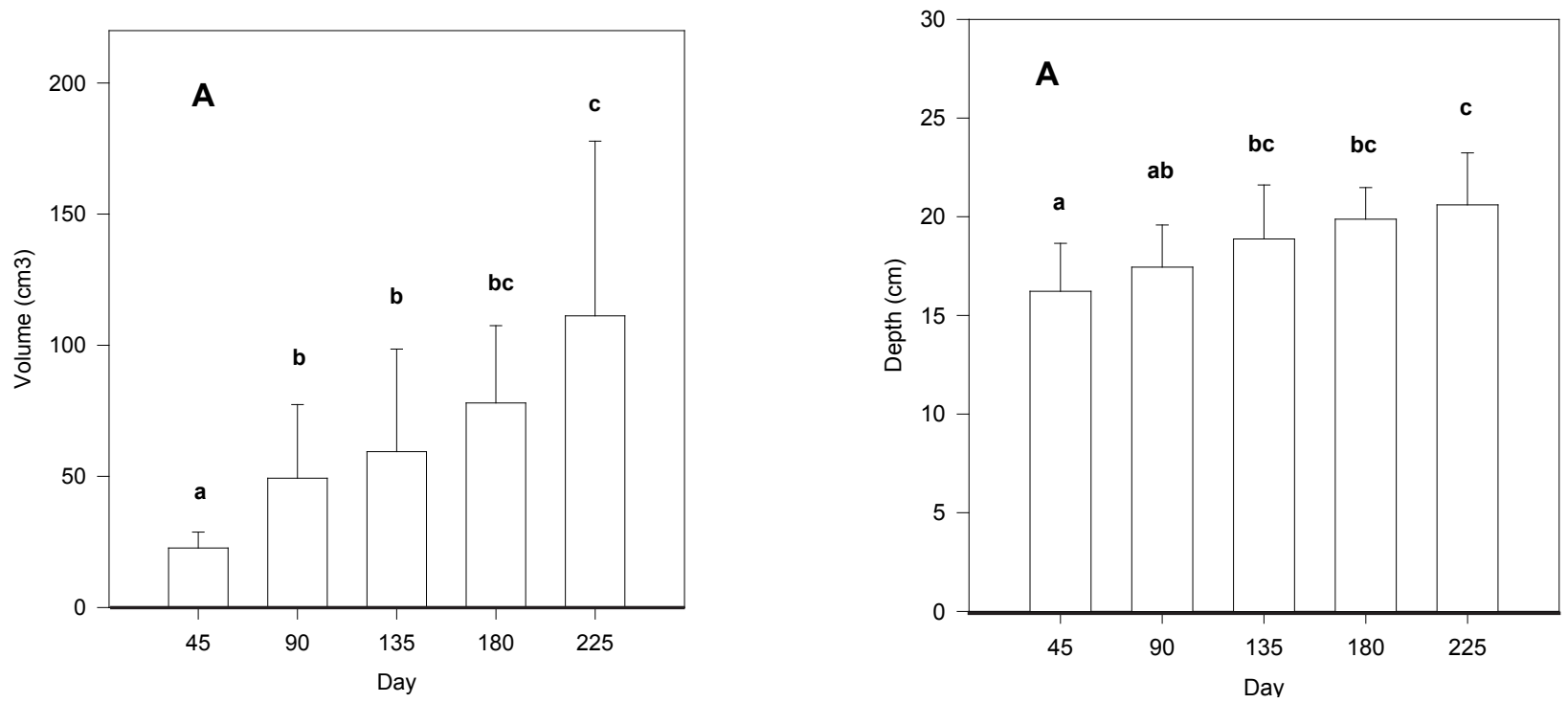

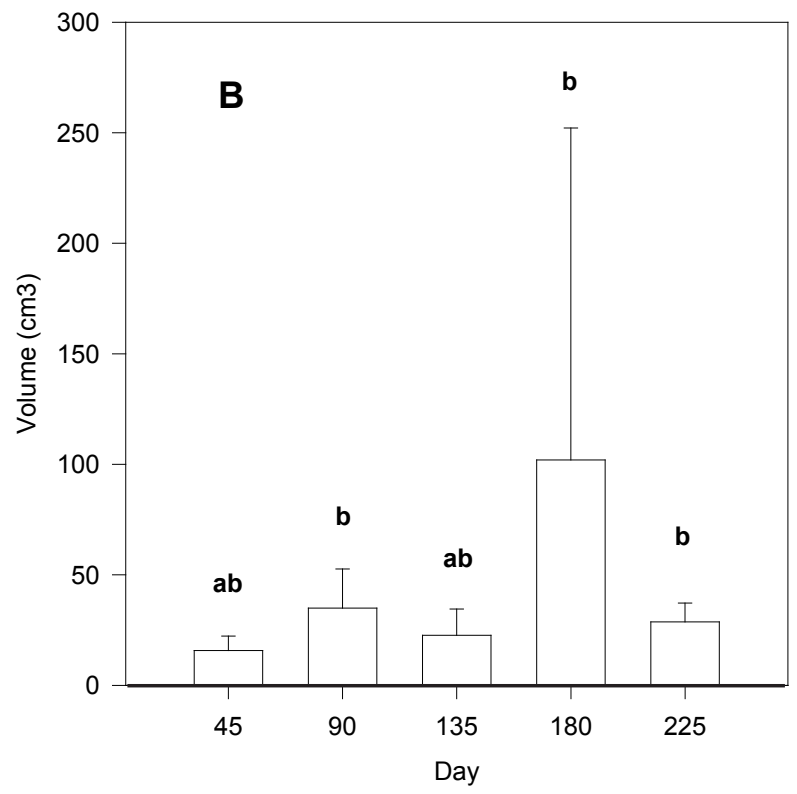

Fig 2. Mean volumes of the initial chamber of Atta bisphaerica (A) and Atta sexdens rubropilosa (B) as a function of time since foundation. Means followed by the same letter are not significantly different (Bonferroni test).

presenting the following measurements: depth of $39 \mathrm{~cm}$, and vol. of $73.8 \mathrm{~cm}^{3}$. In the second nest, the depth was found to be less than $150 \mathrm{~cm}$ (an accurate measurement was not made due to some excavation difficulties).

\section{Discussion}

\section{Format of the initial chamber}

In the present study the occurrence of two shapes, ellipsoid and spherical, was observed in both studied species. The chamber founded by the queen initially presented an ellipsoid format, with changing to a spherical shape proceeded by the excavation by the worker ants. These workers excavated the chamber in all dimensions, but more in width and height than in depth.

The queen body is longer than wider or higher (Moser et al., 2004), so the chamber may also be optimized in this format to just accommodate it and to avoid unnecessary lost energy in digging process by the queen (Camargo et al., 2011). Later, it turns into spherical format, which would be more appropriate (optimized) for growing the fungus by the workers (Römer \& Roces, 2014). 
In both species, the size of the initial chamber increased as a function of time until digging of the second chamber started, approximately 180 days after nest foundation. The enlargement of the chamber probably occurred because of colony population growth, which can explain why $A$. sexdens rubropilosa chambers grew less: although not quantified, $A$. sexdens rubropilosa had fewer ants and smaller symbiotic fungus amounts in each period studied compared to $A$. bisphaerica. These results corroborate Buhl et al. (2004), who verified that the digging activity and volume increase in the initial chamber in Messor sanctar Emery were adjusted to colony population size. Rasse and Deneubourg (2001) also verified that both the volume and the maximum rate of excavation are related to the size of the group, and that the digging activity diminished when a Lasius niger L. nest reaches a particular volume. Similarly, Mikheyev and Tschinkel (2004) confirmed that total nest volume is highly correlated with the number of worker ants in Formica pallidefulva Wheeler. In leaf cutting ants, it is known that the fungus garden acts as a three-dimensional pattern for the final size of the chamber, that is, according to its growth, the ants increase the size of the chambers, as discussed by Fröhle and Roces (2009), Camargo et al. (2013) and Camargo and Forti (2014), for Acromyrmex lundi and A. sexdens rubropilosa, respectively.

Depth

The initial chamber depth significantly differed between the ant species, with $A$. bisphaerica showing deeper chambers than $A$. sexdens rubropilosa. It is known that Atta bisphaerica Forel 1908, presents nests in full sun and foraging predominantly grasses, and Atta sexdens rubropilosa Forel 1908 presents nests in shaded places and forages dicots (Mariconi, 1970; Fowler et al., 1986; Nagamoto et al., 2009), therefore differing in nesting habits and foraging strategies. Probably, the differences in nest depth between species are correlated to soil temperature, because shading alters soil temperature regimes by locally diminishing soil temperature (Rosenberg et al., 1983). In this perspective, we can hypothesize that nest exposed in grassland should have deeper fungus chamber than nest under shade of trees or inside the woods, given that soil temperature is negatively correlated with soil depth (Rosenberg et al., 1983). For leaf cutting ants, is indicated that soil moisture and temperature acts together: ( $i$ ) Bollazzi et al. (2008) verified that workers' thermopreferences lead to the construction of superficial nests in cold soils, and subterranean ones in hot soils; and (ii) Pielström \& Roces (2014) verified that soil moisture also varies according to soil depth, and demonstrably affects the digging behavior of leaf cutting ants.
The excavation of the second chamber by the worker ants occurred 6 months after the nest foundation in both species. This result differs from Mariconi (1970) who describes a 15-month period since foundation for digging the new channel and second chamber of Atta capiguara. However, the results approximate those of Jacoby (1943) who verified in $A$. sexdens rubropilosa the construction of a second chamber at 4 and 5 months after nest foundation. At 180 days of age, despite the presence of a second chamber, symbiotic fungus, workers and queens were still found in the first chamber. For this reason, it is suggested that in this period the new chamber had not been completely constructed, since according to Jacoby (1943), the fungus is established only in finalized chambers. In addition, Camargo and Forti (2013) argued that the structural growth of the nests occurred vertically, without lateral expansion of tunnels and chambers in the first year. The 3-month-old nests had a chamber with an average depth of $15 \mathrm{~cm}$. In the course of 1 year, the nests expanded to have three to four chambers and were 3-4 m deep. The lateral expansion occurred after 1 year, when the nests grew laterally and reached large dimensions when adult ants were 3 years old. For example, adult nests of $A$. laevigata are $7 \mathrm{~m}$ deep, with a number of chambers ranging from 1149 to 7864 and a volume from 0.03 to 51 liters (Moreira et al., 2004).

\section{Conclusion}

It may be suggested from the present study that the worker ants actively dig the initial chamber, causing an increase in its size and influencing its depth to favor the chances of establishment of the colony. Although the adult nests of $A$. sexdens rubropilosa present different depth, chamber number and nest structure from A. bisphaerica, the initial nests are similar in shape as well as the time for construction of the second chamber. However, the initial chambers of $A$. bisphaerica present greater size and depth than those of $A$. sexdens rubropilosa. Besides, the chamber depth of $A$. bisphaerica is deeper than $A$. sexdens rubropilosa.

\section{Acknowledgments}

We wish to thank FAPEMA for the fellowship granted to the first author and FAPESP for financial support (2008/07032-7). L.C. Forti gratefully acknowledges the support of CNPq (472671/2008-1).

\section{References}

Amante, E. (1972). Influência de alguns fatores microclimáticos sobre a formiga saúva Atta laevigata (F. Smith, 1958), Atta sexdens rubropilosa Forel, 1908, Atta 
bisphaerica Forel, 1908 e Atta capiguara Gonçalves, 1944 (Hymenoptera, Formicidade), em formigueiros localizados no estado de São Paulo. Ph.D. Thesis, Escola Superior de Agricultura Luiz de Queiroz, USP. Piracicaba, SP, Brazil.

Araújo, M.S. \& Della Lucia, T.M.C. (1997). Caracterização de ninhos de Acromyrmex laticeps nigrosetosus Forel, em povoamento de eucalipto em Paraopeba (MG). Anais da Sociedade Entomologica do Brasil, 26: 205-207. doi: 10.1590/ S0301-80591997000100029

Autuori, M. (1941). Contribuição para o conhecimento da saúva (Atta spp. - Hymenoptera: Formicidae). I - Evolução do sauveiro (Atta sexdens rubropilosa Forel, 1908). Arquivos do Instituto Biológico, 12: 197-228.

Autuori, M. (1942). Contribuição para o conhecimento da saúva (Atta spp. - Hymenoptera - Formicidae). II - O sauveiro inicial (Atta sexdens rubropilosa, Forel, 1908). Arquivos do Instituto Biológico, 13: 67-86.

Bento, J.M.S., Della Lucia, T.M.C., Muchovej, R.M.C. \& Vilela, E.F. (1991). Influência da composição química e da população microbiana de diferentes horizontes do solo no estabelecimento de sauveiros iniciais de Atta laevigata (Hymenoptera: Formicidae) em laboratório. Anais da Sociedade Entomológica do Brasil, 20: 307-316.

Bollazzi, M., Kronenbitter, J. \& Roces, F. (2008). Soil temperature, digging behaviour, and the adaptive value of nest depth in South American species of Acromyrmex leafcutting ants. Oecologia, 158: 165-175.

Buhl, G.J., Deneubourg, J.L. \& Theraulaz, G. (2004). Nest excavation in ants: group size effects on the size and structure of tunneling networks. Naturwissenschaften, 91: 602-606. doi: 10.1007/s00114-004-0577-x

Camargo, R.S. et al. (2011). Digging effort in leaf-cutting ant queens (Atta sexdens rubropilosa) and its effects on survival and colony growth during the claustral phase. Insectes Sociaux, 58: 17-22. doi: 10.1007/s00040-010-0110-5.

Camargo, R.S. \& Forti, L.C. (2013). Queen lipid content and nest growth in the leaf cutting ant (Atta sexdens rubropilosa) (Hymenoptera: Formicidae). Journal of Natural History, 47: 65-73, doi: 10.1080/00222933.2012.738836

Camargo, R.S., Lopes, J.F. \& Forti, L.C. (2013). O jardim de fungo atua como um molde para a construção das câmaras em formigas cortadeiras? Ciência Rural, 43: 565-570.

Camargo, R.S. \& Forti, L.C. (2014). What is the stimulus for the excavation of fungus chamber in leaf-cutting ants? Acta Ethologica, 17: 1-5.

Fowler, H.G., Forti, L.C.; Pereira-da-Silva, V. \& Saes, N.B. (1986). Economics of grass-cutting ants. In C.S. Lofgren \& R.K. Vander Meer (Eds.), Fire ants and leaf-cutting ants: biology and management (pp.18-35). Boulder: Westview Press.
Fröhle, K. \& Roces, F. (2009). Underground agriculture: the control of nest size in fungus-growing ants. In: G. Theraulaz et al. (Eds.), From insect nest to human architecture (pp. 95104). Venice: European Centre for Living Technology.

Fröhle, K. \& Roces, F. (2012). The determination of nest depth in founding queens of leaf-cutting ants (Atta vollenweideri): idiothetic and temporal control. Journal of Experimental Biology, 215: 1642-1650. doi: 10.1242/jeb.066217.

Gonçalves, C.R. (1960). Distribuição, biologia e ecologia das saúvas. Divulgação Agronômica, 1: 2-10.

Halley, J.D., Burd, M. \& Wells, P. (2005). Excavation and architecture of argentine ant nests. Insectes Sociaux, 52: 350356. doi: 10.1007/s00040-005-0818-9

Hölldobler, B. \& Wilson, E.O. (1990). The ants. Cambridge: Harvard University Press.

Jacoby, M. (1943). Observações e experiências sobre Atta sexdens rubropilosa Forel visando facilitar seu combate. Boletim do Ministério da Agricultura, 32 (5): 1-54.

Jacoby, M. (1950). A arquitetura do ninho. In M. Jacoby (Ed.). A saúva: uma inteligência nociva (pp. 21-31). Rio de Janeiro: Serviço de Informação Agrícola.

Mariconi, F.A.M. (1970). As saúvas. São Paulo: Agronômica Ceres.

Mikheyev, A.S. \& Tschinkel, W.R. (2004). Nest architecture of the ant Formica pallidefulva: structure, costs and rules of excavation. Insectes Sociaux, 41: 30-36. doi: 10.1007/ s00040-003-0703-3

Moreira, A.A. (2001). Atta bisphaerica Forel, 1908 (Hym: Formicidae): arquitetura de ninhos e distribuição de isca nas câmaras. Ph.D. Thesis, Faculdade de Ciências Agronômicas, UNESP. Botucatu, SP, Brazil.

Moreira, A.A., Forti, L.C., Andrade, A.P.P., Boaretto, M.A.C., Lopes, J.F.S. (2004). Nest architecture of Atta laevigata (F. Smith, 1858) (Hymenoptera: Formicidae). Studies on Neotropical Fauna and Environment, 39: 109-116.

Moser, J.C., Reeve, J.D., Bento, J.M.S., Della Lucia, T., Cameron, R.S. \& Heck, N.M. (2004). Eye size and behaviour of day-and night-flying leafcutting ant alates. Journal of Zoology, 264: 69-75.

Nagamoto, N.S., Carlos, A.A., Moreira, S.M., Verza, S.S., Hirose, G.L. \& Forti, L.C. (2009). Differentiation in selection of dicots and grasses by the leaf-cutter ants Atta capiguara, Atta laevigata and Atta sexdens rubropilosa. Sociobiology, 54: 127-138.

Pereira-da-Silva, V. (1979). Dinâmica populacional, biomassa e estrutura dos ninhos iniciais de Atta capiguara Gonçalves, 1944 (Hymenoptera: Formicidae) na região de Botucatu, SP. Livre Docência Thesis, Instituto de Biociências, UNESP. Botucatu, SP, Brazil. 
Pielström, S. \& Roces, F. (2014). Soil moisture and excavation behaviour in the Chaco leaf-cutting ant (Atta vollenweideri): digging performance and prevention of water inflow into the nest. PLoS ONE 9(4): e95658. doi:10.1371/journal. pone. 0095658

Pretto, D.R. (1996). Arquitetura dos túneis de forrageamento e do ninho de Atta sexdens rubropilosa Forel, 1908 (Hymenoptera - Formicidae), dispersão de substrato e dinâmica do inseticida na colônia. M.Sc. Dissertation, Faculdade de Ciências Agronômicas, UNESP. Botucatu, SP, Brazil.

Rasse, P.H. \& Deneubourg, J.L. (2001). Dynamics of nest excavation and nest size regulation of Lasius niger (Hymenoptera: Formicidae). Journal of Insect Behavior, 14 (4): 433-449. doi: 10.1023/A:1011163804217
Ribeiro, F.J.L. (1995). A escavação do solo pela fêmea da saúva (Atta sexdens rubropilosa). Psicologia-USP, 6: 75-93.

Römer, D. \& Roces, F. (2014). Nest enlargement in leafcutting ants: relocated brood and fungus trigger the excavation of new chambers. PLoS ONE, 9 (5): e97872. doi:10.1371/ journal.pone.0097872

Rosenberg, N.J., Blad, B.L., \& Verma, S.B. (1983). Microclimate-the biological environment. New York: Wiley.

Silva Junior, M.R., Castellani, M.A., Moreira, A.A., D’Esquivel, M., Forti, L.C. \& Lacau, S. (2013). Spatial distribution and architecture of Acromyrmex landolti Forel (Hymenoptera, Formicidae) nests in pastures of Southwestern Bahia, Brazil. Sociobiology, 60: 20-29.

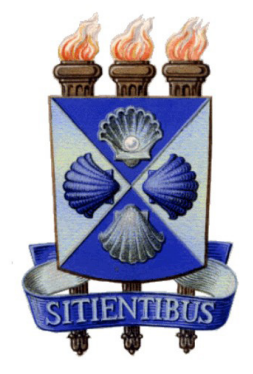

